\title{
PENGEMBANGAN KEWIRAUSAHAAN FAKULTAS PERTANIAN BERBASIS SUMBERDAYA LOKAL
}

\author{
Tri Martial ${ }^{1)}$, Mhd. Asaad ${ }^{2)}$, Supriadi $^{3)}$, Mahyu Danil $^{4)}$, Desi Novita ${ }^{5}$ \\ Universitas Islam Sumatera Utara ${ }^{1)}$ \\ Universitas Islam Sumatera Utara ${ }^{2)}$ \\ Universitas Islam Sumatera Utara ${ }^{3)}$ \\ Universitas Islam Sumatera Utara ${ }^{4}$ \\ Universitas Islam Sumatera Utara ${ }^{5}$ ) \\ trimartial@gmail.com
}

\begin{abstract}
ABSTRAK
Tujuan dari program pengembangan kewirausahaan (PPK) di Fakultas Pertanian (FP) Universitas Islam Sumatera Utara (UISU) adalah untuk membina, mendidik dan mengembangkan kewirausahaan bagi mahasiswa dan alumni berdasarkan spesifikasi produk dalam rangka menghasilkan wirausahawan muda yang kreatif, inovatif dan mampu bersaing dalam dunia bisnis. Sementara target spesifik adalah untuk menghasilkan pengusaha baru dengan berbagai keuntungan dari produk berbasis sumber daya lokal. Metode yang digunakan untuk mencapai tujuan ini melalui serangkaian kegiatan terstruktur dimulai dengan perekrutan 20 peserta, diikuti oleh pendidikan dan pelatihan manajemen bisnis, seperti manajemen produksi, manajemen pemasaran, manajemen keuangan. Peserta juga ikut serta dalam magang di industri mitra, kemudian kegiatan pengembangan produk berbasis sumber daya lokal dilakukan. Kegiatan pembinaan dan pendampingan dilakukan selama pelaksanaan program. Hasil kegiatan menunjukkan bahwa kewirausahaan pertanian berbasis sumber daya lokal lebih berfokus pada menjaga kualitas produk untuk mendapatkan pasar yang sesuai. Produk kewirausahaan tergantung pada kondisi lingkungan. Output dari kegiatan PPK diproduksi minimal 5 (lima) Pengusaha baru setiap tahunnya. Termasuk jurnal nasional dengan ISSN, publikasi di media massa, dan produk barang yang dihasilkan.
\end{abstract}

Keywords: kewirausahaan, pendidikan, pengusaha, manajemen bisnis, magang

\begin{abstract}
The purpose of the Entrepreneurship Development Program (PPK) at the Faculty of Agriculture University of Islamic Sumatera Utara (UISU) is to foster, educate and develop entrepreneurship for students and alumni based on product specifications in order to produce young entrepreneurs who are creative, innovative and able to compete in the business world. While the specific target is to produce new entrepreneurs with a variety of advantages of local resource-based products. The method used to achieve this goal through a series of structured activities began with the recruitment of 20 participants, followed by a series of education and training on business management, such as production management, marketing management, financial management. Participants also take part in an internship in the partner industry, then local resource-based product development activities are carried out. Coaching and mentoring activities are carried out throughout the program's implementation. The results of the activities show that local resource-based agricultural entrepreneurship focuses more on maintaining the quality of the product to get an appropriate market. Entrepreneurial products depend on environmental conditions. The output of PPK activities is produced at least 5 (five) new entrepreneurs each year. Including the National Journal with ISSN, publications in the mass media, and goods produced.
\end{abstract}

Keywords: entrepreneurship, education, entrepreneur, business management, internships

\section{PENDAHULUAN}

\subsection{Analisis Situasi}

Kondisi kewirausahaan di

Universitas Islam Sumatera Utara

(UISU) selama ini sudah mulai tumbuh dan berkembang di beberapa Fakultas dan Program Studi. Seperti Misalnya di Fakultas Pertanian (FP), terdapat beberapa kelompok mahasiswa yang mengembangkan berbagai aktifitas kewirausahaan, diantaranya: 1) Usaha 
membuat abon berbasis ternak ikan lele, produk makanan ringan berbasis bahan dasar lokal, produk pengemasan minyak wangi, serta beberapa kegiatan lain berbasis produk pangan. 2) Sedangkan di Fakultas Ilmu Keguruan dan Ilmu Pendidikan telah mengembangkan berbagai produk bersumber dari bahanbahan lokal seperti pupuk organik, pangan organik dan bahan-bahan pangan lain yang bersifat organik.

Universitas Islam Sumatera Utara (UISU) dengan jumlah mahasiswa sekitar 6.000 orang adalah potensi yang besar untuk kegiatan kewirausahaan. Berbagai program kemahasiswaan telah dilakukan di UISU selama ini oleh Pusat Pengembangan Kewirausahaan dan Ketenagakerjaan (P2K2) UISU. Lembaga P2K2 secara khusus berpran dalam pembinaan kewirausahaan dan pelatihan serta penyaluran lulusan ke dunia kerja dan dunia usaha. Program kewirausahaan secara kontinyu dilakukan mulai dari rekrutmet mahasiswa dan alumni sebagai tenant, diikuti dengan pelatihan manajemen bisnis dan pengembangan produk, serta magang di perusahaan atau magang usaha. Kegiatan yang telah dilakukan tersebut selama ini merupakan program dengan dana internal UISU.

$$
\text { Beberapa produk Program }
$$

Kreativitas Mahasiswa (PKM) mahasiswa UISU diantaranya adalah: Abon berbahan ikan lele dan jantung pisang yang dikembangkan oleh mahasiswa Fakultas Pertanian UISU; Pupuk kompos dan pupuk cari sebagai hasil produk fermentasi bahan organic yang dikembangkan oleh jurusan Pendidikan Kimia UISU; Produk minyak wangi berbahan alami yang dikembangkan oleh mahasiswa Fakultas Pertanian UISU. Produk-produk pangan lain yang dikembangkan sebagai pangan tambahan yang dikembangkan oleh mahasiswa dari beberapa Fakultas.
Tingginya minat mahasiswa dan alumni dibidang kewirausahaan menunjukkan potensi UISU yang besar dalam menghasilkan wirausahawanwirausahan baru dengan berbagai produk yang inovatif. Namun saat ini kegiatan kewirausahaan masih berupa internal pendanaan dari UISU. Sedangkan upaya untuk meningkatkan standar kegiatan PKM telah dilakukan melalui berbagai kegiatan pelatihan/workshop penulisan proposal PKM.

Memperhatikan perkembangan kewirausahaan mahasiswa di UISU yang masih sedikit, maka perlu upaya yang signifikan untuk memacu dan mendorong tumbuhnya wirausaha baru sebagai luaran UISU yang nantinya dapat berperan serta dalam meningkatkan kesejahteraannya serta dapat membina calon-calon wirausaha yang lain. Menurut Kemristek Dikti (2017), program kegiatan penting bagi pendidikan tinggi untuk menghasilkan wirausaha adalah program yang dibuat secara terpadu, seperti melaksanakan program belajar bekerja terpadu (PBBT). Dengan program PBBT tersebut mahasiswa memperoleh pengalaman kerja dan dapat mengatasi masalah yang dihadapi dalam berwirausaha. Pendekatan program secara terpadu inilah yang akan dikembangkan di Fakultas Pertanian UISU. Potensi yang dominan pada mahasiswa UISU khususnya Fakultas Pertanian adalah mahasiswa dan alumni yang merintis usaha baru. Oleh sebab itu program PPK di Fakultas Pertanian ini berusaha untuk mengembangkan berdasarkan potensi mahasiswa dan alumni didominasi oleh mahasiswa dan alumni yang merintis usaha baru atau berminat menjadi wirausahawan.

Keunggulan iptek dalam kegiatan PPK ini adalah menciptakan atau mengembangkan produk-produk tenant 
berbasis kepada sumberdaya lokal. Hal ini seperti studi Djodjobo C.V.dan H. N. Tawas (2014) yang meneliti usaha pemilik nasi kuning di Manado, menyebutkan untuk bersaing didalam dunia usaha, maka harus dilakukan orientasi kewirausahaan dan inovasi produk secara simultan. Ketika perusahaan mempunyai keunggulan bersaing maka akan berpengaruh positif terhadap kinerja pemasaran. Seperti diketahui faktor keberhasilan pemasaran merupakan penentu keberhasilan suatu usaha.

Keunggulan kegiatan PPK ini sebagai upaya menggali kelebihan atau kekhususan sumberdaya lokal terutama dibidang pertanian. Di bidang agribisnis produk tenant diarahkan dalam rangka memanfaatkan sumber-sumber yang tersedia secara lokal. Produk tanaman dari usaha agribisnis didorong memanfaatkan bahan-bahan yang yang tersedia dan mengembangkannya menjadi produk inovatif. Di bidang pangan diupayakan bahan baku untuk produk tenant bersumber dari bahanbahan yang juga tesedia secara lokal. Keunggulan berbasis sumberdaya lokal ini menjadi arah dalam mengembangkan produk setiap tenant.

\subsection{Permasalahan Mitra}

Permaslahan utama mitra PPK di Fakultas pertanian UISU Inisiasi yang telah dilakukan masih sangat terbatas program-program yang dilakukan dalam menumbuh-kembangkan jiwa kewirausahaan pada mahasiswa maupun alumni. Berbagai kegiatan kewirausahaan yang ada dilakukan secara perseorangan dalam kontek kreatifitas mandiri. Hal ini penting dilakukan untuk meng-inisiasi kewirausahaan secara melembaga yang dilakukan dalam program yang terkoordinasi.

Permaslahan diatas pada dasarnya disebabkan oleh pendidikan kewirausahaan belum dilakukan secara sistematis dalam model pembelajaran berkelanjun. Model pembelajaran tersebut harus dibangun sebagai suatu kegiatan terstruktur untuk membina kapasitas, membuka peluang usaha, serta mampu untuk menjalankannya sebagai output pendidikan.

\section{METODE PELAKSANAAN}

Pelaksanaan program pegembangan kewirausahaan di Fakultas Pertanian UISU dimulai dari rekrutmen calon perserta/tenant. Rekrutment tenant dilakukan secara terbuka kepada mahasiswa dan alumni UISU Medan. Kriteria yang ditetapkan bahwa calon tenant mempunyai keterlibatan dalam kegiatan kewirausahaan, baik dalam tahap awal maupun pengembangan usaha. Pemenuhan kriteria ini sangat penting karena menjadi dasar keberhasilan program PPK ini nantinya. Calon tenant yang punya motivasi tinggi relatif lebih berhasil dalam kewirausahaan (Ryani Dhyan, 2012). Berdasarkan kriteria tersebut dilakukan seleksi untuk mendapatkan 20 tenant yang memenuhi kualifikasi dan bersedia terlibat didalam program PPK sampai selesai. Melalui berbagai proses kegiatan di PPK, pada akhir program setiap tahunnya ditargetkan menghasilkan minimal 5 (lima) orang wirausaha baru

Metode yang diterapkan dalam kegiatan PPK ini sesuai dengan tujuan untuk menghasilkan wirausahawan baru, adalah: 1) Rekrutment, 2) Pendidikan dan pelatihan, 3) Magang pada industry/usaha mitra, 4) Pengembangan produk tenat , 5)Pembimbingan dan pendampingan, 6) Pengawasan kegiatan tenant, dan 7) Pola pembiayaan usaha tenant, serta 8) Bantuan teknologi/peralatan untuk menyelesaikan masalah tenant. 


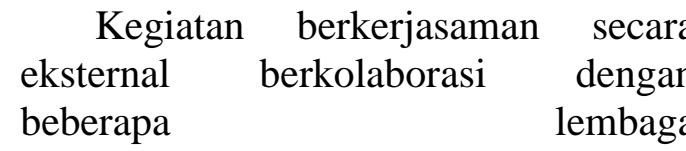

kewirausahaan/pengusaha yang telah dilakukan UISU melalui beragam kerjasama dalam pembimbingan dan pembinaan kewirausahaan mahasiswa dan alumni. Perusahaan-perusahaan tersebut menjadi tempat/lpkasi magang bagi peserta/tenant. Selain itu kolaborasi juga dilakukan secara internal dengan lembaga pusat pengembangan kewirausahaan dan ketenagakerjaan (P2K2) yang selama ini telah banyak melakukan berbagai kegiatan pelatihan kewirausahaan bagi mahasiswa dan alumni UISU.

\subsection{Persiapan}

Langkah persiapan kegiatan PPK FP UISU, adalah melakukan berbagai koordinasi antar lembaga, yaitu Rektorat, Fakultas Pertanian, Lembaga Pengabdian kepada Masyarakat dan P2K2. Hal ini dilakukan untuk mendapatkan kesamaan pemahaman bahwa program dilaksanakan sebagai upaya untuk mempersiapkan masasiwa dan alumni UISU menjadi wirausaha. Hal ini sesuai dengan visi UISU untuk membagikan ilmu kepada masyarakat sehingga dicintai oleh masyarakat. Dukungan berbagai lembaga tersebut juga bertujuan untuk memudahkan pelaksanaan PPK dengan melakukan pembinaan mitra lintas Fakultas dan Program studi (bukan hanya mahasiswa dan alumni dari Fakultas Pertanian). Persiapan lanjutan adalah ruang kantor/kerja yang digunakan sebagai pusat pelayanan mitra dan koordinasi Antara Tim pelaksana. Ruang rapat/pelatihan juga diperlukan untuk melaksanakan pertemuan dan pelatihan mitra. Hal ini penting dilakukan sehingga pemanfaatan ruang dapat digunakan secara terjadwal.

\subsection{Pelaksanaan.}

Pelaksanaan kegiatan PPK melalui serangkaian kegiatan sebagai berikut:

a) Rekrutment.

Rekrutment dilaksanakan secara terpusat oleh Tim Pelaksana dalam suatu Tim rekrutment yang dibentuk untuk mendapatkan calon tenant sebanyak 20 orang. Kriteria yang ditetapkan bahwa calon tenant telah mempunyai keterlibatan dalam kegiatan kewirausahaan, baik dalam tahap awal maupun pengembangan usaha. Sedangkan bagi calon tenant yang belum mempunyai usaha, namun mempunyai hasrat yang kuat menjadi wirausahawan dapat dipertimbangkan menjadi peserta. Calon tenat, baik sudah atau belum mempunyai usaha dipilih berdasarkan motivasi mengikuti kegiatan PPK. Calon wajib memiliki motivasi tinggi scara internal maupun eksternal. Faktor-faktor internal berupa motivasi, sedangkan factor eksternal adalah daya dukung lingkungan termasuk keluarga (Siswadi, 2013). Pemenuhan kriteria diatas sangat penting karena menjadi dasar keberhasilan program PPK. Menurut Ryani Dhyan (2012) Calon tenan yang punya motivasi tinggi relatif lebih berhasil dalam kewirausahaan.

b) Langkah kedua adalah pendidikan dan pelatihan

Pendidikan dan pelatihan yang meliputi manajemen bisnis dimana peserta (mitra) dididik dengan serangkaian pemahanan bisnis oleh nara sumber yang kompeten serta praktisi bisnis yang sukses (best practice).

c) Ketiga adalah magang pada industri/ usaha mitra.

Hal ini dilakukan setelah peserta/tenant mendapat serangkaian pemahaman tentang bisnis. Kegiatan bertujuan untuk memberi praktik langsung kepada para tenant terhadap 
berbagai aspek bisnis, seperti manajemen dan produksi, serta cara mengatasi berbagai permasalahan yang dimadapi dalam aspek-aspek bisnis tersebut. Kegiatan magang berupaya menghadapkan tenant dengan praktek langsung di perusahaan mitra. Hal ini agar tetant mendapatkan pengalaman langsung yang secara kongkret dapat dilaksanakan nantinya. Kegiatan kongkret ini wajib disiapkan dalam program ini sebagai pembelajaran kongkret bagi tenant. Menurut Aprijon (2013) program pembelajaran kewirausahaan melalui para praktisi harus lebih konkret dalam menyiapkan kegiatan pembelajaran yang benarbenar dapat mendorong tumbuh dan berkembangnya spirit kewirausahaan.

d) Pengembangan produk

Pengembangan produk dilakukan terhadap produk-produk tenant yang sudah ada atau pengembangan produk. Hal ini bertujun untuk memberi spesifikasi khusus terhadap produk yang dimaksud. Pengembangan produk sebagai keunggulan dengan memanfaatkan bahan-bahan sebagai sumberdaya lokal. Hal ini mempunyai ciri yang spesifik serta mudah didapatkan, dengan demikian pengembangan produk bertujuan agar produk mempunyai keunggulan spesifik lokal namun dapat diterima dalam jumlah luas.

Keunggulan produk yang dikembangkan dalam PPK ini adalah berbasis sumberdaya lokal. Usaha tenant yang berbasis agribisnis dengan cara melakukan pendekatan secara terpadu terhadap berbagai sumberdaya alam yang tersedia secara lokal sebagai upaya pendekatan agribisnis secara terpadu. Pendekatan usaha berbasis agribisnis terpadu merupakan pendekatan usaha tani/ bisnis yang lebih efisien (Departemen Agribisnis IPB, 2004). Hal ini dilakukan dengan menggunakan elemen-elemen terkait sebagai kesatuan yang saling mendukung.

Dalam pengembangan produk ini dibutuhkan kreativitas untuk mendapatkan produk-produk yang inovatif dan berorientasi pasar. Kreativitas dalam pengembangan produk, orisinalitas produk, dan diversifikasi produk mempunyai peran dominan dalam pemasaran yang menjadi penentu keberhasilan wirausahawan (Hadiyati, E., 2012; Setyawati, E.C.N., Nugraha, H.S.,dan I. Ainuddin, 2013).

e) Pembimbingan dan pendampingan.

Kegiatan pembinaan dan pendampingan dilakukan secara terus menerus selama program kegiatan PPK dilaksanakan. Hal ini dilakukan oleh Tim pelaksana bekerjsama dengan LPKM UISU dan P2K2 UISU. Kegiaan bertujuan agar para tenant dapat langsung berkunsultasi untuk mengatasi berbagai permasalahan yang dihadapi secara langsung. Tim pelaksana, LPKM serta P2K2 membuat jadwal kunjungan secara terstruktur untuk melakukan pembimbingan dan pendampingan tersebut.

f) Pengawasan kegiatan tenant.

Pengawasan dilakukan secara terjadwal selama program PPK. Pengawasan bertujuan untuk memastikan kegiatan berjalan sesuai dengan perencanaan, termasuk mengembangkan produk-produk inovatif.

g) Pola pembiayaan usaha tenant.

Perbaikan pola pembiayaan dilakukan melalui pelatihan, asistensi dan bimbingan langsung usaha tenant. Perbaikan pembiayaan usaha tenant juga dilakukan melalui pendampingan langsung sistem keuangannya. 
h) Bantuan teknologi/peralatan untuk membantu usaha tenant.

Dilakukan dengan memberikan bantuan teknologi/peralatan yang dibutuhkan oleh tenant untuk meningkatkan volume usaha atau mengembangkan produk inovatif. Jumlah tenant yang dibina setiap tahun adalah sebanyak 20 orang. Setiap akhir tahun akan dilepas minimal 5 orang sebagai wirausaha baru. Setiap akhir tahun dilakukan evaluasi terhadap para tenant. Evaluasi tenant dikelompokkan kedapa tiga kelompok yaitu: wirausaha baru, tenant prospek dan tenant nonprospek. Wirausaha baru adalah para tenant yang sudah mampu untuk mandiri menjalankan usahanya. Tenant prospek adalah tenant yang belum mampu mandiri dan masih membutuhkan pembinaan, serta tenant non-prospek adalah tenant yang didak dapat lagi dilanjutkan pembinaannya setelah satu tahun tersebut. Tenant nonprospek tidak dapat dilanjutkan pembinaan pada tahun kedua.

i) Evaluasi Kegiatan

$$
\text { Evaluasi kegiatan dilakukan }
$$

setiap akhir tahun dengan memperhatikan hal-hal sebagai berikut: Aktifitas tenant mengikuti program PPK, Kinerja usaha tenant, Pruduksi dan pengembangan produk, Keuntungan, Permasalahan tenant, dan Ketercapaian program Tim PPK.

Evaluasi tersebut bertujuan untuk menilai capaian kinerja tenant, baik dalam mengikuti program PPK, maupun capaian dalam keberlangsungan usahanya. Disini dilakukan pengelompokan tenant kepada tiga kelompok : wirausaha baru, tenant prospek dan tenant non-prospek. Hal ini bertujuan untuk rencana kegiatan PPK tahun selanjutnya, serta dapat sebagai umpan balik bagi perbaikan PPK selanjutnya. Pengelompokan tersebut menjadi dasar bagi calon peserta (tenant) di tahun selanjutnya.

\section{HASIL DAN PEMBAHASAN}

Kegiatan kewirausahaan dalam rangka memdidik dan mengembangkan kewirausahaan di Fakultas Pertanian menekankan kepada pengusaha berbasis sumberdaya oleh, mekanisme untuk menghasilkan wirausaha tersebut adalah:

\section{Kegiatan rekrutasi}

Kegitan rekrutasi melalui serangkaian kegiatan pengumuman dan wawancara dilakukan untuk mendapatkan calon mitra yang memenuhi kriteria. Tim rekrutment mendapatkan calon tenant sebanyak 20 orang. Kriteria yang ditetapkan bahwa calon tenant telah mempunyai keterlibatan dalam kegiatan kewirausahaan, baik dalam tahap awal maupun pengembangan usaha. Sedangkan bagi calon tenant yang belum mempunyai usaha, namun mempunyai hasrat yang kuat menjadi wirausahawan dapat dipertimbangkan menjadi peserta. Calon tenat, baik sudah atau belum mempunyai usaha dipilih berdasarkan motivasi mengikuti kegiatan PPK. Calon wajib memiliki motivasi tinggi scara internal maupun eksternal. Faktor-faktor internal berupa motivasi, sedangkan factor eksternal adalah daya dukung lingkungan termasuk keluarga (Siswadi, 2013). Pemenuhan kriteria diatas sangat penting karena menjadi dasar keberhasilan program PPK. Menurut Ryani Dhyan (2012) Calon tenan yang punya motivasi tinggi relatif lebih berhasil dalam kewirausahaan.

\section{Kegiatan pengarahan dan} motivasi

Kegiatan pengarahan dan motivasi awal dilakukan dalam rangka menyamakan persepsi para peserta 
dalam mengikuti kegiatan kewirausahaan di Fakultas Pertanian UISU. Hal-hal terkait dengan rencana kegiatan untuk melaksanakan seluruh

kegiatan dalam tahun berjalan. Berikut beberapa kegiatan tersebut pada Gambar1.

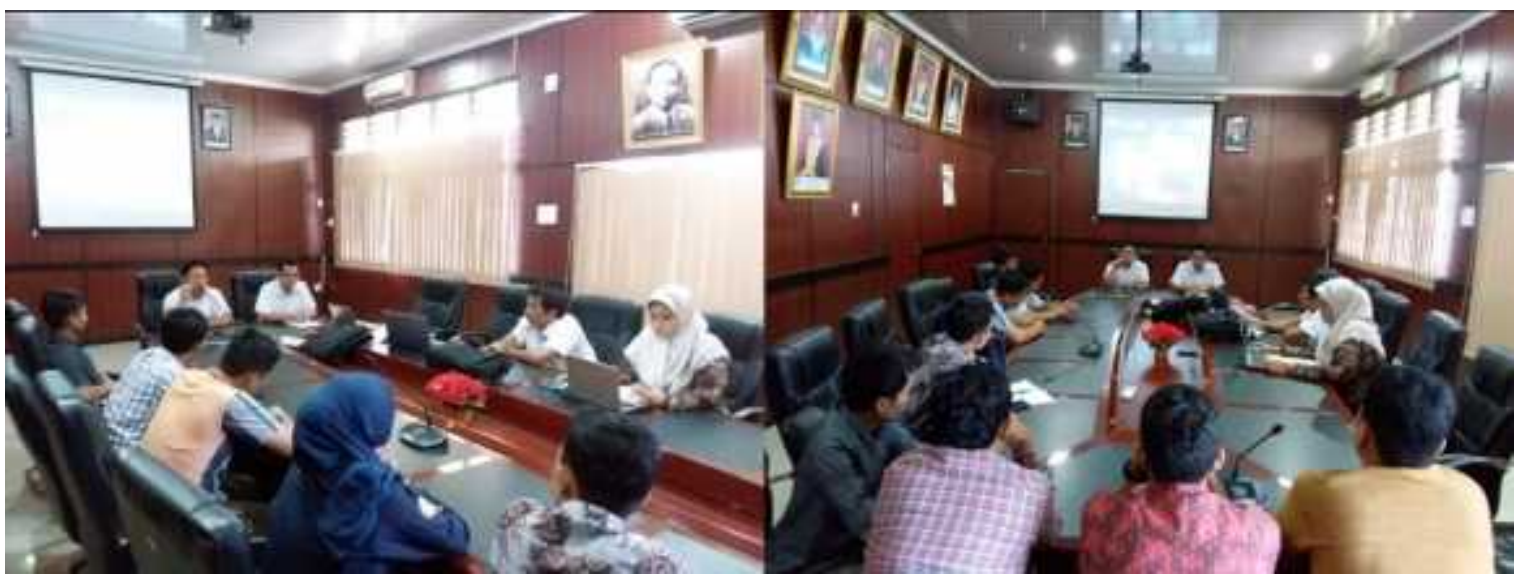

Gambar 1. Kegiatan Pengarahan dan Motivasi

3. Kegiatan pelatihan

Kegiatan pelatihan Pertama dilakukan tentang dasar-dasar wirausaha, dimana untuk membangun wirausaha baru memerlukan berbagai pendekatan secara teoritis. Pelatihan ini disampaikan oleh Bapak Abdul Haris (pada Gambar 2), seorang akademisi yang memahami tentang kewirausahaan.

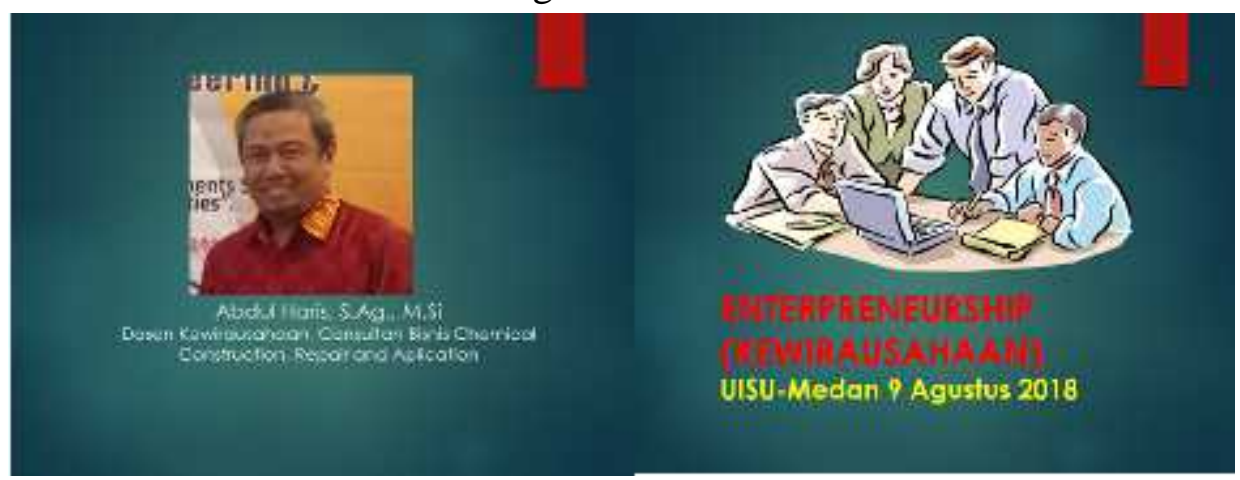

Gambar 2. Pelatihan Kewirausahaan

Materi lain adalah: bagaimana membangun kewirausahaan baru yang disampaikan oleh Ibu Dina yang adalah seorang praktisi memiliki berbagai macam usaha yang didirikan olehnya secara langsung (Gambar 3).

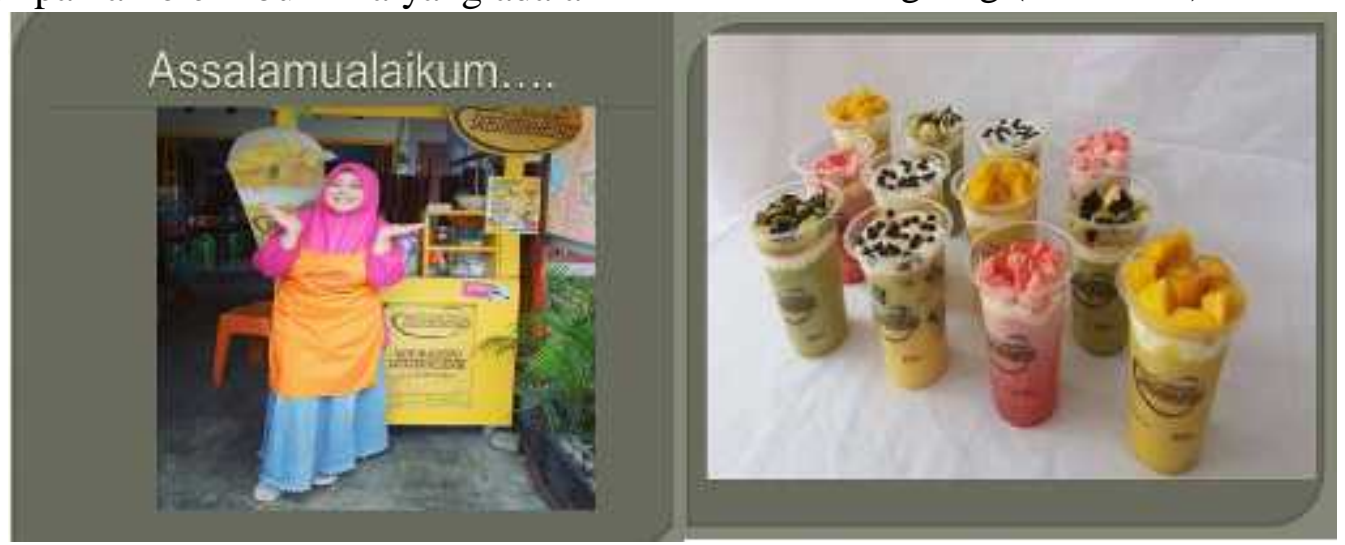




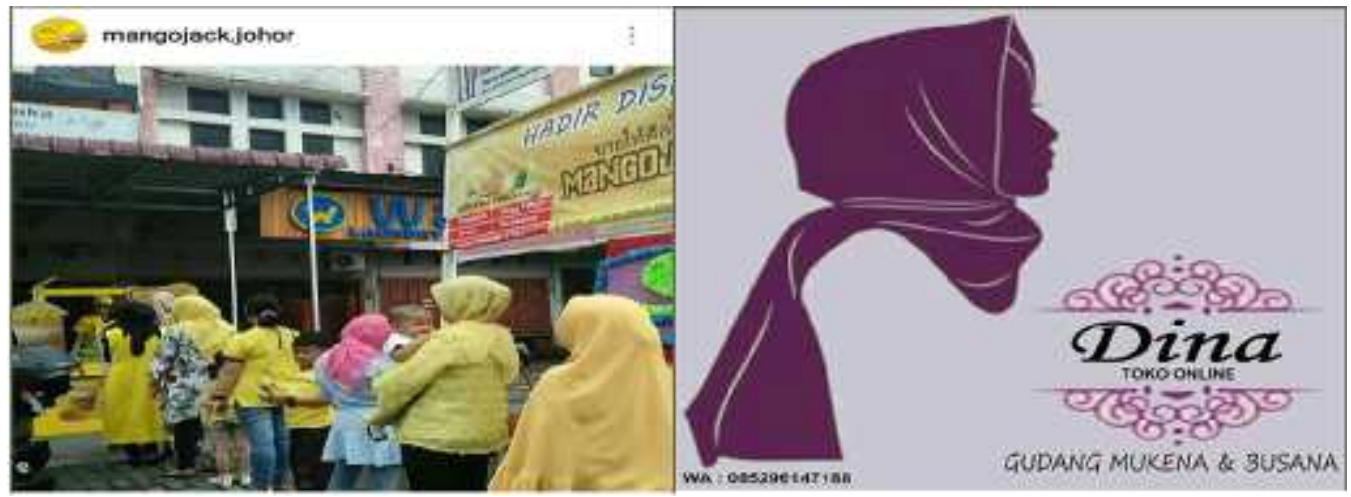

Gambar 3. Pelatihan Membuat Usaha baru

\section{Magang UKM}

Kegiatan magang UKM adalah berupaya mendidik secara langsung kepada calon wirausahawan untuk mendapatkan pengalaman secara langsung (Gambar 4). Magang bermanfaat sangat positif untuk membangun jiwa kewirausahaan. Hal ini disebabkan tantangan dalam magang diperoleh secara langsung ketika dihadapkan dengan konsumen. Magang saat ini dilakukan dibeberapa unit usaha UKM berikut:

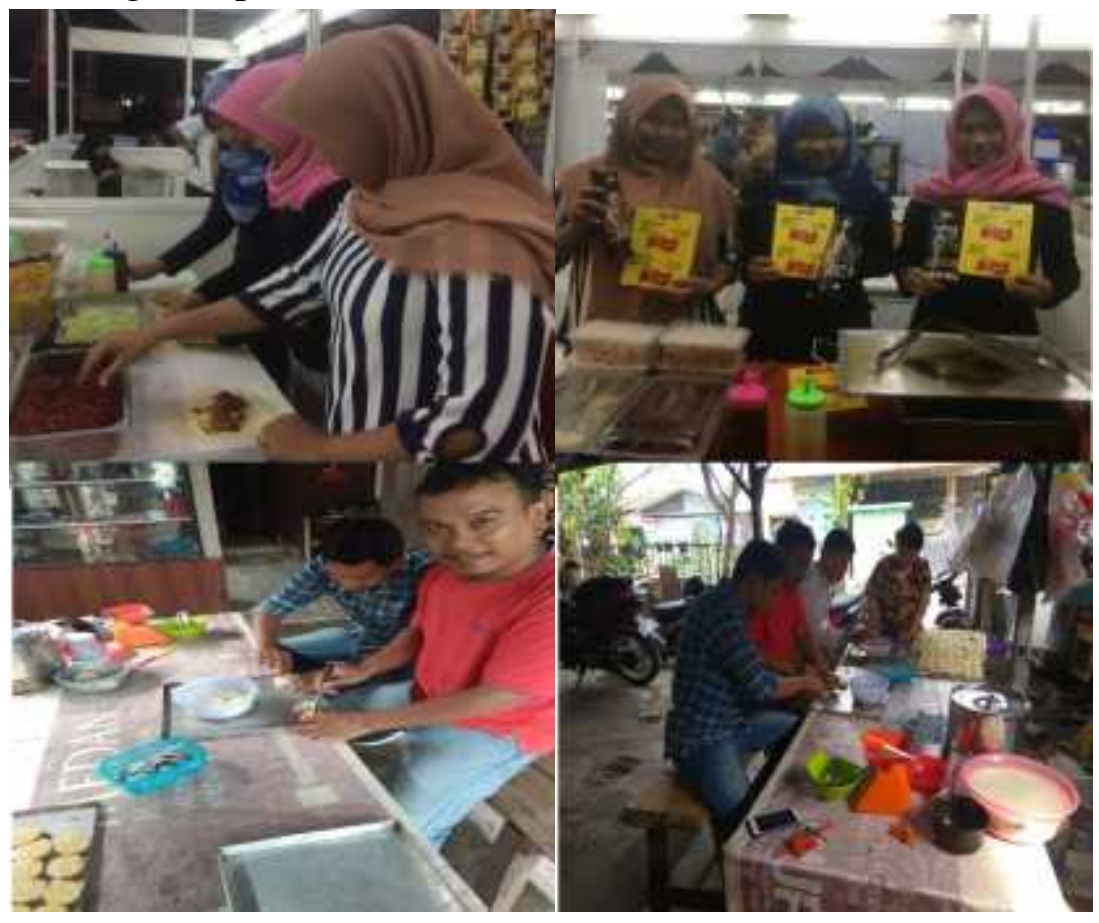

Gambar 4. Magang UKM

5. Bantuan Teknologi

Bantuan teknologi/peralatan untuk membantu usaha tenant. Bantuan teknologi disesuaikan dengan kebutuhan masing-masing tenant sebanyak 5 (orang) yang dinilai berhasil melaksanakan kegiatan kewirausahaan Gambar 5). 


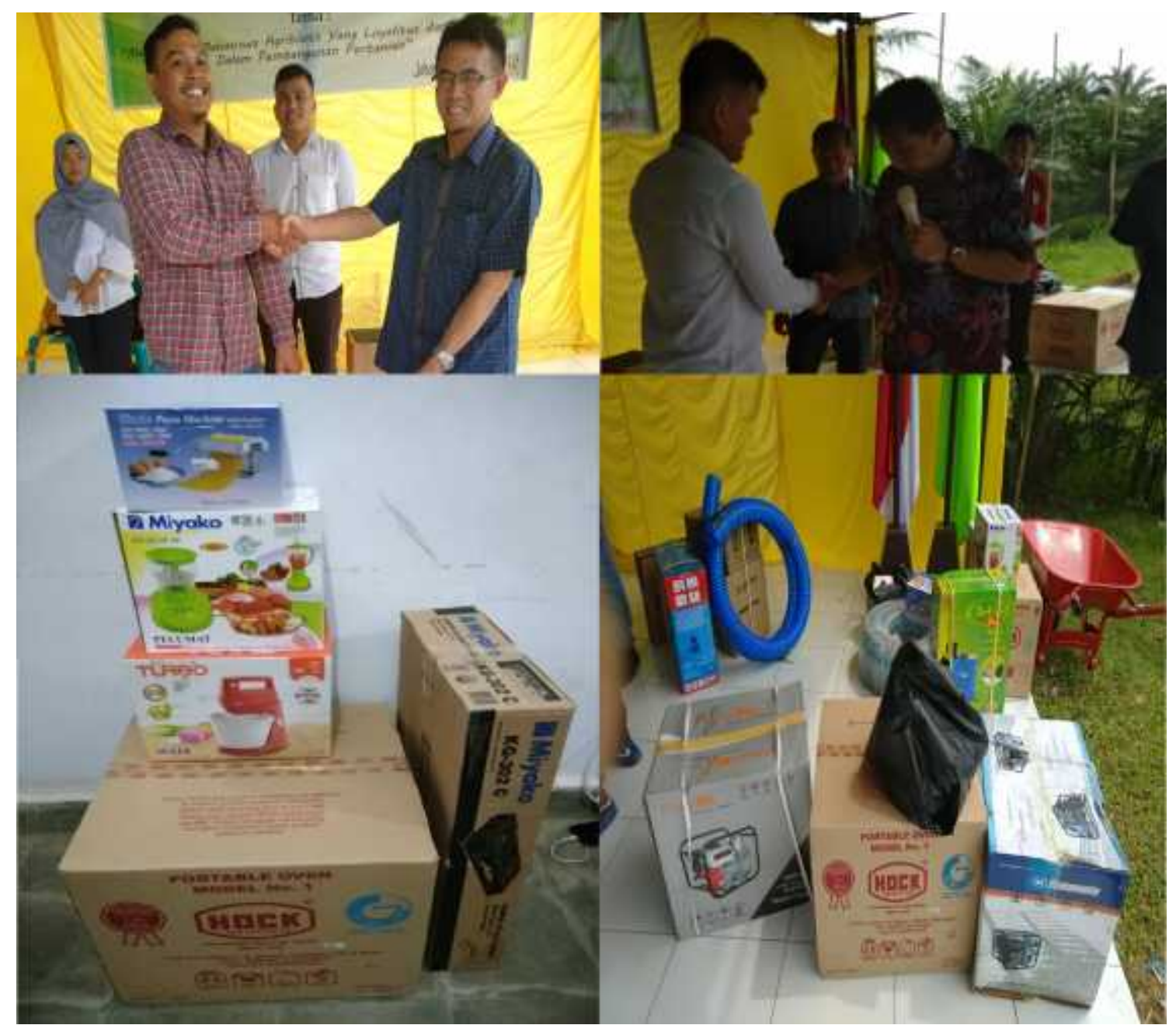

Gambar 5. Bantuan Peralatan kepada Wirausahawan baru

\section{Produk}

Ragam produk yang dihasilkan dari kegiatan kewirausahaan di Fakultas pertanian adalah produk-produk berbasis sumberdaya lokal, diantaranya: budidaya hortikultura, pangan beras, makanan (kuliner) berbasis nabati dan produk makanan lainnya. Namun berdasarkan kondisi produksi di lapangan, hal ini dapat berubah-ubah tergantung kepada musim untuk produk berbasis budidaya tanaman. Begitu juga dengan produk-produk pangan, produk seringkali masih daihasilkan secara proradis dan belum kontinyu. Oleh sebab itu pengembangan produk masih harus tetap ditingkatkan selama kegiatan ini berlangsung. Direncanakan kegiatan secara terus menerus dilakukan selama dalam masa program berjalan sampai dihasilkan wirausahawan baru di Fakultas Pertanian UISU, seperti: Pengembangan produk tenat, Pembimbingan dan pendampingan, Pengawasan kegiatan tenant, Pola pembiayaan usaha tenant, dan Bantuan teknologi/peralatan untuk menyelesaikan masalah tenant

Kegiatan PPK sebagai lembaga yang terstruktur di Fakultas Pertnaian UISU direncanakan mempunyai keberlanjutan setiap tahunnya. Hal ini dilandasi oleh visi UISU untuk membangun masyarakat dan membina mahasiswa dan alumni UISU untuk mampu bersaing setelah selesai 
pendidikannya. Membina mahasiswa dan alumni menjadi seorang wirausahawan merupakan langkah penting bagi alumni untuk bekerja setelah tamat, dengan tidak bergantung kepada ketersediaan lapangan kerja yang terbatas. Visi UISU yang Islami, andal dan teruji, mengarahkan lulusannya untuk mampu berperan sebagai seorang wirausahawan sesuai dengan nilai-nilai Islam itu sendiri (Subur, 2007).

Berbagai upaya yang dapat ditempuh dalam mengembangkan kewirausahaan di UISU sebagai dampak positif program PPK adalah: (1) dicantumkan mata kuliah kewirausahaan dalam kurikulum setiap program studi di perguruan tinggi yang secara kurikuler wajib diikuti oleh semua mahasiswa; (2) pengembangan Program Belajar Bekerja Terpadu yaitu program pendidikan yang memadukan belajar dan bekerja seperti karyawan dalam dunia, terutama bagi mahasiswa tingkat akhir; (3) kerjasam sama dengan UMKM; (4) pendirian Koperasi Mahasiswa; dan (5) pelaksanaan kerja sampingan mahasiswa baik sesuai dengan bidang ilmunya atau sesuai dengan bakat dan hobinya meskipun tidak sesuai dengan bidang ilmunya (Wahyuni, E.T, 2008). Kegiatan tersebut menjadi target pengembangan kewirausahaan UISU kedepan. Sebagai penerjemahan visi UISU untuk dapat berperan sarta dalam upaya mengurangi kemiskinan, maka pendidikan kewirausahaan penting sebagai bentuk pembelajaran (Winarningsih,S., 2006).

\section{KESIMPULAN DAN SARAN}

\subsection{Kesimpulan}

Pemahaman mitra terhadap kewirausahaan berada pada level yang beragam, dimana beberapa mahasiswa sudah dpat menjalankan usaha dan beberapa lainnya masih dalam penjajagan untuk memulai usaha. Upaya untuk mendorong mitra menjadi wirausaha terutama hambatannya adalah dari dalam diri mitra sendiri (internal). Upaya untuk mendidik menjadi wirausaha di Fakultas Pertanian UISU membutuhkan pendekatan secara terus menerus dan jangka panjang.

\subsection{Saran}

Untuk membangun kewirausahaan dapat tumbuh dan berkembang dilingkungan Universitas seperti UISU dibutuhkan dukungan dari semua pihak secara internal. Hal ini dapat dimulai dari kurikulum di Universitas.

\section{UCAPAN TERIMAKASIH}

Ucapan terimakasih yang setinggitingginya disampaikan kepada Dirjen Dikti Depdikbud yang telah memberikan dana kegiatan pengabdian kepada masyarakat Program Pengembangan Kewirausahaan (PPK), sehingga kegiatan ini dapat dilakukan

\section{REFERENSI}

Aprijon. 2013. Kewirausahaan dan Pandangan Islam. Jurnal Menara, Vol. 12 No. 1 Januari - Juni 2013

Departemen Agribisnis IPB. 2004. Kewirausahaan dan Inovasi usaha Agribisnis. Disampaikan pada Lokakarya dan Pembekalan Tim Pelaksana Program Mitra Desa Institut Pertanian Bogor, Senin, 24 April 2004

Djodjobo C.V. dan H. N. Tawas. 2014. Pengaruh Orientasi Kewirausahaan, Inovasi Produk, Dan Keunggulan Bersaing Terhadap Kinerja Pemasaran Usaha Nasi Kuning Di Kota Manado. Jurnal EMBA Vol.2 No.3 September 2014, Hal. 12141224 
Hadiyati, E. 2012. Kreativitas Dan Inovasi Pengaruhnya Terhadap Pemasaran Kewirausahaan Pada Usaha Kecil. Jurnal Inovasi dan Kewirausahaan Vol 1 No. 3 Sep 2012 Hal 135-151

Kemristek Dikti. 2017. Panduan Program Kewirausahaan Mahasiswa Indonesia

Ryani Dhyan. 2012. Kewirausahaan I. Pusat Buku Ajar dan e-learning http://www.mercubuana.ac.id

Setyawati, E.C.N., Nugraha, H.S., Ainuddin, I. 2013. Karakteristik Kewirausahaan Dan Lingkungan Bisnis Sebagai Faktor Penentu Pertumbuhan Usaha. Jurnal Administrasi Bisnis, Volume 2, Nomor 1, Maret 2013

Siswadi. 2013. Analisis Faktor Internal, Faktor Eksternal Dan Pembelajaran Kewirausahaan Yang Mempengaruhi Minat Mahasiswa Dalam Berwirausaha. Jurnal manajemen \& Bisnis vol 13 no. 01 april 2013 ISSN 16937619

Subur. 2007. Islam dan Mental Kewirausahaan: Studi tentang Konsep dan Pendidikannya. Jurnal Pemikiran Alternatif Pendidikan Insania|Vol. 12|No. 3|Sep-Des 2007|341-354

Wahyuni, E.T.. 2008. Upaya Menumbuhkembangkan

Kewirausahaan Di Kalangan Mahasiswa. Jurnal AKMENIKA UPY, Volume 2, 2008

Winarningsih, S. 2006. Menyikapi Globalisasi dan Meningkatkan Budaya Kewirausahaan Disampaikan pada: Seminar Kewirausahaan dan Usaha Mikro Kecil Menengah Gedung Wahana Bakti Pos Jl. L.R.E Martadinata Bandung, 25 Maret 2006 